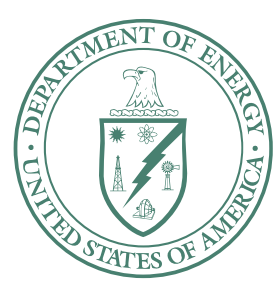

U.S. Department of Energy

Idaho Operations Office

\title{
Final Removal Action Report for the CPP-603A Basin Facility
}

January 2007 
DOE/ID-11306

Revision 1

\section{Final Removal Action Report for the CPP-603A Basin Facility}

January 2007

Prepared for the

U.S. Department of Energy

DOE Idaho Operations Office 


\begin{abstract}
This Final Removal Action Report describes the actions that were taken under the non-time-critical removal action recommended in the Action Memorandum for the Non-Time Critical Removal Action at the CPP-603A Basins, Idaho Nuclear Technology and Engineering Center, as evaluated in the Engineering Evaluation/Cost Analysis for the CPP-603A Basin Non-Time Critical Removal Action, Idaho Nuclear Technology and Engineering Center. The Removal Action implemented consolidation and recording the location of debris objects containing radioactive cobalt (cobalt-60), removal and management of a small high-activity debris object (SHADO 1), the removal, treatment, and disposal of the basin water at the Idaho CERCLA Disposal Facility (ICDF) evaporation ponds, and filling the basins with grout/controlled low strength material. The Engineering Evaluation/Cost Analysis for the CPP-603A Basin Non-Time Critical Removal Action, Idaho Nuclear Technology and Engineering Center - conducted pursuant to the Comprehensive Environmental Response, Compensation, and Liability Act — evaluated the risks associated with deactivation of the basins and alternatives for addressing those risks. The decision to remove and dispose of the basin water leaving debris not containing uranium in the basins to be grouted in place after the sludge had been removed and managed under the Hazardous Waste Management Act/Resource Conservation and Recovery Act was documented in the Action Memorandum for the Non-Time Critical Removal Action at the CPP-603A Basins, Idaho Nuclear Technology and Engineering Center.
\end{abstract}




\section{CONTENTS}

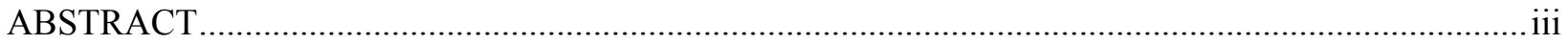

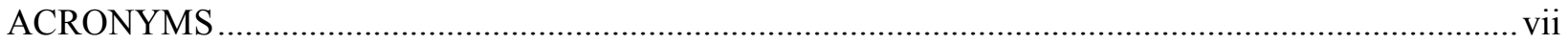

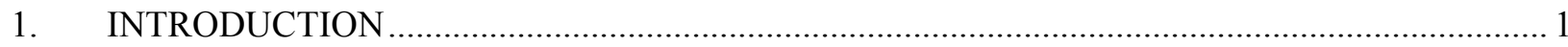

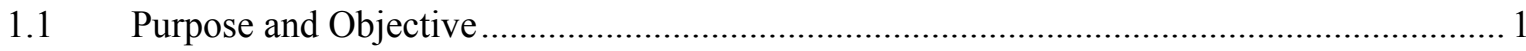

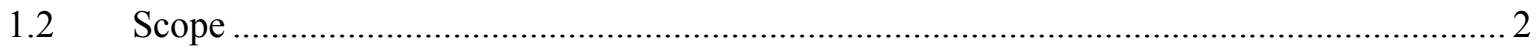

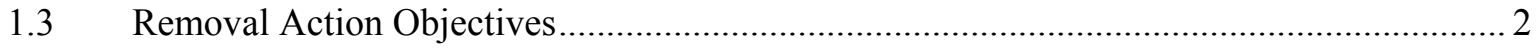

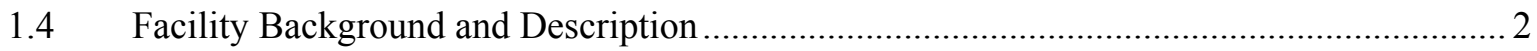

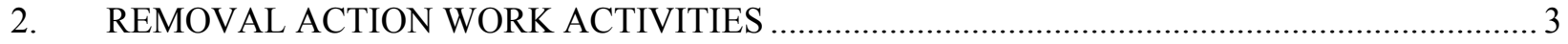

2.1 Sludge Removal, Treatment, and Disposal ................................................................ 3

2.2 Consolidation and Location of Cobalt-60 Containing Debris ......................................... 4

2.3 Removal of the Small High-Activity Debris Object (SHADO 1) ..................................... 4

2.4 Basin Water Removal, Treatment, and Disposal and Filling the Basins with

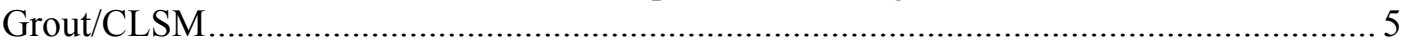

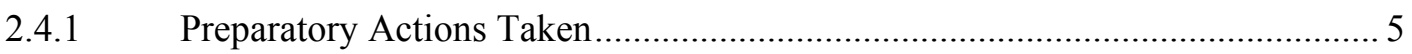

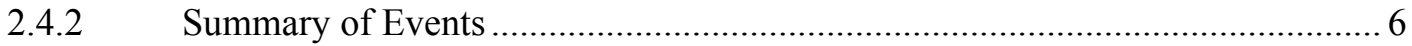

3. ACHIEVING THE REMOVAL ACTION OBJECTIVES ........................................................ 10

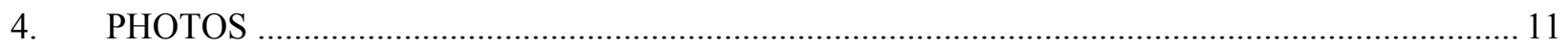

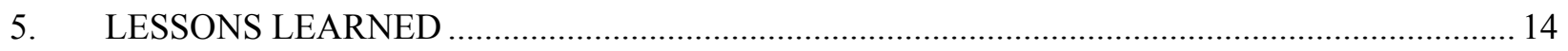

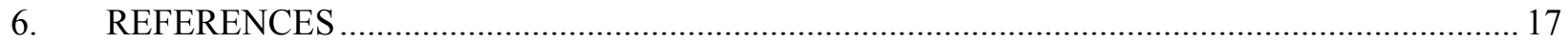




\section{FIGURES}

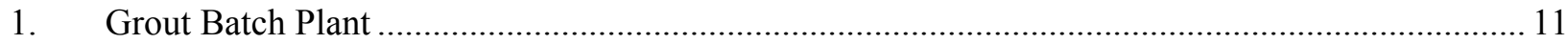

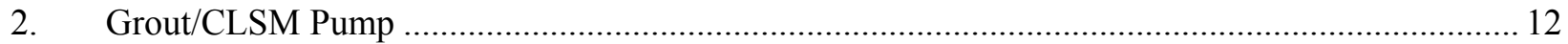

3. Basin Water Discharge to ICDF Evaporation Pond …............................................................ 12

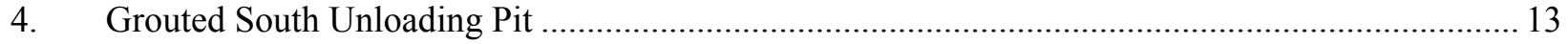

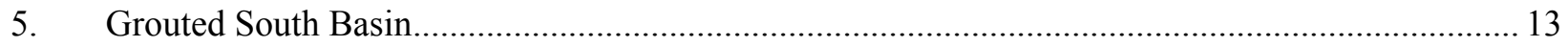

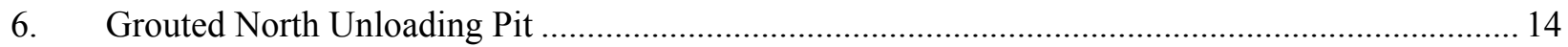

TABLES

1. Pre-grouting and Post-grouting Radiological Conditions in CPP-603A …...................................... 8

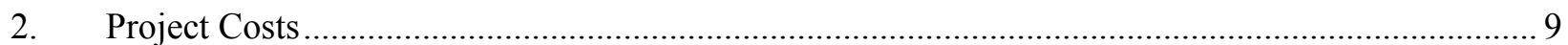




\section{ACRONYMS}

CERCLA Comprehensive Environmental Response, Compensation, and Liability Act

CLSM controlled low strength material

CPP Chemical Processing Plant (now INTEC)

CWI CH2M-WG Idaho, LLC

DEQ Idaho Department of Environmental Quality

DOE U.S. Department of Energy

EPA U.S. Environmental Protection Agency

HIC High-Integrity Container

HWMA Hazardous Waste Management Act

ICDF Idaho CERCLA Disposal Facility

IFSF Irradiated Fuels Storage Facility (CPP-603)

INEEL Idaho National Engineering and Environmental Laboratory (now INL)

INL Idaho National Laboratory (was INEEL)

INTEC Idaho Nuclear Technology and Engineering Center (was CPP)

MSA management self-assessments

RCRA Resource Conservation and Recovery Act

RWMC Radioactive Waste Management Complex

SHADO small high-activity debris object

TSS Total Suspended Solids

USC United States Code

WAC Waste Acceptance Criteria 


\section{Final Removal Action Report for the CPP-603A Basin Facility}

\section{INTRODUCTION}

\subsection{Purpose and Objective}

This Final Removal Action Report describes the actions taken under the non-time-critical removal action recommended in the Action Memorandum for the Non-Time Critical Removal Action at the CPP-603A basins, Idaho Nuclear Technology and Engineering Center (DOE-ID 2005), as evaluated in the Engineering Evaluation/Cost Analysis for the CPP-603A Basin Non-Time Critical Removal Action, Idaho Nuclear Technology and Engineering Center (DOE-ID 2004). The regulatory framework outlined in the Removal Action Work Plan was modified from the description provided in the Engineering Evaluation/Cost Analysis (DOE-ID 2004). The modification affects regulation of sludge removal, treatment, and disposal, but the end state and technical approaches did not change. Removal, treatment, and disposal of the basin water and placement of grout/controlled low strength material (CLSM) in the basins was initiated after successful removal, treatment, and disposal of the basin sludge. The Engineering Evaluation/Cost Analysis - conducted pursuant to the Comprehensive Environmental Response, Compensation, and Liability Act (CERCLA) (42 United States Codes [USC] § 9601 et seq.) - evaluated the risks associated with the sludge and basin water and the alternatives for addressing those risks. A decision was made to address the sludge under the Hazardous Waste Management Act/Resource Conservation and Recovery Act (HWMA/RCRA) (Idaho Code $\S 39-4401$ et seq.; 42 USC $§ 6901$ et seq.).

The Chemical Processing Plant (CPP)-603A basin facility is located at the Idaho Nuclear Technology and Engineering Center (INTEC) at the U.S. Department of Energy's (DOE's) Idaho National Laboratory (INL; formerly the Idaho National Engineering and Environmental Laboratory [INEEL]) in Butte County, Idaho. The Final Record of Decision Idaho Nuclear Technology and Engineering Center, Operable Unit 3-13 (DOE-ID 1999) governs CERCLA sites within the INTEC facility designated as Waste Area Group 3. Therefore, implementation of this CERCLA removal action is consistent with the remedial action objectives established in the Final Record of Decision (DOE-ID 1999).

The recommended action identified in the Action Memorandum (DOE-ID 2005) was to perform interim stabilization of the basins. The sludge in the basins was removed and treated in accordance with the HWMA/RCRA (Idaho Code $\S 39-4401$ et seq.; 42 USC $\S 6901$ et seq.). The scope of the non-timecritical removal action included consolidation and recording the location of one debris objects containing radioactive cobalt (cobalt-60), removing and managing a small high-activity debris object (SHADO 1); removing, treating, and disposing of the basin water; and filling the basins with grout/CLSM. The basin water was removed while the basins were being filled with grout/CLSM to minimize exposure of the contaminated scum line. Debris objects containing radioactive cobalt (cobalt-60) were consolidated into or near the three carbon steel boxes located in the South Basin and encapsulated in the grout/CLSM. The position of these debris objects has been recorded to facilitate future location and removal, if necessary. The grout/CLSM also provides shielding and containment for the radioactive contamination embedded in the basin walls, minimizing migration and airborne contamination. The Removal Action Work Plan used the term "debris" to refer to both radioactive and nonradioactive materials in the basins. The terms "debris" and "debris objects" are used to refer to 14 discrete, highly radioactive objects that were sitting on the basin floor as well as a variety of nonradioactive hand tools and general rubbish inadvertently dropped in the basins over the years. The basin water was pumped to the Idaho CERCLA Disposal Facility (ICDF) evaporation ponds. The final decontamination and disposition of the basin structure will 
be evaluated when the entire CPP-603 Complex is taken out of service. The non-time-critical removal action was an interim action to reduce the risks to human health, the environment, and site workers by minimizing the potential for release of hazardous substances. The interim action does not prejudice the final end-state alternative.

\subsection{Scope}

The scope of the activities addressed by the Removal Action Work Plan included consolidation and recording the location of the previously identified debris objects containing radioactive cobalt (cobalt-60) (completed in January 2005) and removal and relocation of SHADO 1 (completed in March 2005). Additional highly radioactive activated metal was located during sludge removal activities. The newly identified material was isolated and consolidated with the previously identified cobalt- 60 contaminated material before basin water removal and basin filling was initiated. Additional scope completed includes removing and pumping approximately 1.2 million gallons of basin water to the ICDF evaporation ponds and placing approximately $6,500 \mathrm{yd}^{3}$ of grout/CLSM in the basins. Grout/CLSM was placed in the basins while water was pumped to maintain a relatively constant water level to shield and contain the radioactive contamination near the top of the basin walls.

Other activities occurred in conjunction with the activities described in the Removal Action Work Plan. The removal, treatment, and disposal of the basin sludge took place prior to dewatering and grout/CLSM placement and was conducted in accordance with the HWMA/RCRA (Idaho Code $\S 39-4401$ et seq.; 42 USC $\S 6901$ et seq.).

\subsection{Removal Action Objectives}

The removal action was consistent with the remedial action objectives established in the Final Record of Decision (DOE-ID 1999). As such, the removal action is consistent with and will contribute to the overall remediation of INTEC under CERCLA (42 USC $\S 9601$ et seq.).

The removal action objectives are described in Section 4.1.1 of the Action Memorandum (DOE-ID 2005). The mechanisms implemented under this non-time-critical removal action that achieved Removal Action Objectives are described in Section 3 of this document.

\subsection{Facility Background and Description}

The storage basins are reinforced concrete structures with most of their volume below grade. Each of the three basins and the Transfer Canal was filled with water. The combined volume of water in the storage basins and Transfer Canal was estimated to be $5.30 \mathrm{E}+06 \mathrm{~L}(1.40 \mathrm{E}+06$ gal). This volume estimate includes the volume filled by beams and columns within the North and Middle basins.

The North and Middle Basins are $17.5 \mathrm{~m}(57.5 \mathrm{ft})$ long, $11.4 \mathrm{~m}(37.5 \mathrm{ft})$ wide, and $6.4 \mathrm{~m}(21 \mathrm{ft})$ deep. Each of the basins is $1.28 \mathrm{E}+03 \mathrm{~m}^{3}\left(1.68+03 \mathrm{yd}^{3}\right)$ in volume. The basins and Transfer Canal are covered with fiberglass grating and a radiation shield consisting of lead plate sandwiched between aluminum plates supported by concrete beams and columns on two foot centers forming 29 storage rows per basin.

The South Basin is an open basin, $12.8 \mathrm{~m}(42.0 \mathrm{ft}) \times 23.6 \mathrm{~m}(77.25 \mathrm{ft})$ in area and $6.4 \mathrm{~m}(21 \mathrm{ft})$ deep. The total volume of the South Basin is $1.93 \mathrm{E}+03 \mathrm{~m}^{3}\left(2.52 \mathrm{E}+03 \mathrm{yd}^{3}\right)$. The South Basin contains three storage boxes. The $1 \times 1 \times 1.2-\mathrm{m}(3 \times 3 \times 4$-ft $)$, open-top carbon steel boxes, now encapsulated in the grout/CLSM, contain the miscellaneous debris, including cobalt-60 debris objects. 
A $2.2 \times 61.0 \times 6.4-\mathrm{m}(7 \times 200 \times 21-\mathrm{ft})$ Transfer Canal connected the three storage basins. The total volume of the Transfer Canal is $8.6 \mathrm{E}+02 \mathrm{~m}^{3}\left(1.09 \mathrm{E}+03 \mathrm{yd}^{3}\right)$. A floor grating overlaid with aluminum-clad lead-plate shielding covers the Transfer Canal. The monorail track extends overhead on both sides of the Transfer Canal.

The non-time-critical removal action, which was an interim action, applied to the CPP-603A basin system, including the Fuel Element Cutting Facility transfer tunnel, the overflow pit, the north and south transfer stations, and the transfer canal. Deactivation, decontamination, and decommissioning of the other currently unused portions of CPP-603A will be coordinated with the final deactivation, decontamination, and decommissioning of the CPP-603 Complex. The CPP-603B (Irradiated Fuel Storage Facility) is expected to remain active until approximately 2035. Currently, the basin water treatment system is being closed under the Voluntary Consent Order in accordance with the requirements of HWMA/RCRA (Idaho Code § 39-4401 et seq.; 42 USC § 6901 et seq.). Preparation to close the VES-SFE-106 waste tank system in accordance with HWMA/RCRA requirements is also underway.

\section{REMOVAL ACTION WORK ACTIVITIES}

The actions addressed in the Removal Action Work Plan are consistent with Alternative 3 described in the Engineering Evaluation/Cost Analysis (DOE-ID 2004). The sludge in the basins was removed and treated in accordance with HWMA/RCRA requirements (Idaho Code $\S 39-4401$ et seq.; 42 USC $\S 6901$ et seq.) prior to the removal action activities. The non-time-critical removal action included consolidating cobalt-60 containing debris; removing SHADO 1; removing, treating, and disposing of the basin water; and filling the basins with grout/CLSM. The tasks accomplished at the removal action site are described below, including a brief discussion of the sludge removal, treatment, and disposal.

DOE-ID has prepared a characterization plan (DOE/ID-11260, "Characterization Plan for Soils Around Drain Line PLA-100115") to conduct soil sampling and analysis around the failed drain line (3 1/2 inch PLA-100115) that transferred water from the decontamination wash pad to the VES-SFE-126 waste tank. This action is a commitment made in the HWMA/RCRA Less Than 90-day Generator Closure Report for the VES-SFE-126 (INEEL 2000). With the water removed from the basins and the threat to the environment posed by the questionable integrity of the basin mitigated, the characterization plan specifying methods for determining the nature and extent of contamination will be implemented as a separate action.

\subsection{Sludge Removal, Treatment, and Disposal}

The CPP-603A basins contained an estimated 49,300 kg (110,200 lbs) of sludge. The sludge was composed of desert sand, dust, precipitated corrosion products, and metal particles from past cutting operations. The sediment also contained radioactive contamination and hazardous constituents, including uranium-235, cadmium, and lead. A decision was made to manage the sludge in accordance with the requirements of the HWMA/RCRA (Idaho Code $\S 39-4401$ et seq.; 42 USC $\S 6901$ et seq.). Sludge removal, treatment, and disposal were conducted under a subcontract issued to EnergySolutions, Inc. (formerly Duratek Federal Services, Inc). The sludge from the CPP-603A basins was removed and treated prior to implementation of dewatering and grout placement activities. Removal of the sludge occurred while the basins remained in service. The sludge was removed and treated to meet RCRA Land Disposal Restriction standards and the Radioactive Waste Management Complex (RWMC) waste acceptance criteria (WAC). 
The removal, treatment, and disposal of the sludge were completed in April 2006, prior to dewatering and grout/CLSM placement at the CPP-603 facility. Once the sludge was removed from the basins and successfully treated, it was transported to the RWMC for disposal.

\subsection{Consolidation and Location of Cobalt-60 Containing Debris}

All discrete, high-activity cobalt-60 containing metal pieces identified during basin scanning were consolidated into the three existing "hot waste boxes" in the South Basin by the end of January 2005. Prior to water removal and grout/CLSM placement in the basins, all newly identified nonfissile debris were also consolidated in or near the "hot waste boxes" and the location of the debris noted for future reference. The "hot waste boxes" are located $20 \mathrm{ft}$ from the east wall and range from 8 to $12 \mathrm{ft}$ from the north wall of the South Basin. The debris objects are now encapsulated and shielded by the grout/CLSM placed in the basins. If the end state selected for the CPP-603 Complex includes removing the basins and the debris objects, the location of the objects has been recorded, as described above, to allow workers to readily locate them for removal in the future if deemed necessary.

\subsection{Removal of the Small High-Activity Debris Object (SHADO 1)}

The SHADO 1 identified in the South Basin during basin scanning was removed from the basin by March 2005 under the Removal Action Work Plan. The SHADO 1 was described in detail in the Engineering Evaluation/Cost Analysis (DOE-ID 2004). The sequence of events implemented by INTEC Operations personnel to manage SHADO 1 was as follows:

- While the SHADO 1 was still in the South Basin, operations personnel manually transferred it using long-reach tools to a basket suitable for dry storage in the Irradiated Fuel Storage Facility (IFSF)

- $\quad$ The basket was transferred to a transport and interim storage package

- $\quad$ The transport-storage package with the basket containing SHADO 1 was removed from the CPP-603 South Basin

- $\quad$ The SHADO 1 object was transported to the IFSF according to the IFSF fuel transfer schedule

- $\quad$ The SHADO 1 was placed into an IFSF fuel storage canister with similar material and will be stored in the IFSF for the foreseeable future.

Two additional highly radioactive debris objects were located and the determination was made to manage them as fuel during sludge removal activities. Those objects were isolated in the South Basin until sludge removal was completed in that area. Prior to placement of grout in the basins, the objects were removed and managed in the same manner as the SHADO 1 object. 


\subsection{Basin Water Removal, Treatment, and Disposal and Filling the Basins with Grout/CLSM}

Upon completion of the preliminary activities, including removal, treatment, and disposal of basin sludge; consolidation of nonfissile debris; and management of SHADO 1; preparations for removal and disposal of basin water and filling the basins with grout/CLSM were initiated.

\subsubsection{Preparatory Actions Taken}

Before dewatering and grout/CLSM placement could be implemented, several actions had to be completed in preparation for the Removal Action. The following activities were completed prior to removal of basin water and grout/CLSM placement.

\subsubsection{Post-sludge Removal Basin Water Characterization}

Sampling procedure SPR-126, "Characterization of CPP-603 Basin Water and In-line Filters (ESP-016-06)" was prepared and implemented to characterize the basin water in CPP-603A. The basin water was sampled and analyzed to confirm that the character of the water had not been significantly degraded by sludge removal activities. Sampling and analysis confirmed that the concentration of dissolved radiological material was reduced as a result of sludge removal.

EDF-4666 demonstrated that the basin water met all ICDF WAC and determined the concentration of radionuclides in the sediment limited the amount of sediment that could remain suspended in the water as total suspended solids (TSS) to about $500 \mathrm{mg} / \mathrm{L}$ to maintain the total radionuclide concentration in the water below the ICDF concentration limits. This limit in the sediment was defined by the reference radionuclide, barium-137m (Ba-137m). Near the end of the grout/CLSM placement process, the $500 \mathrm{mg} / \mathrm{L}$ TSS limit was eliminated as a procedural requirement after it was confirmed analytically that the solids suspended in the basin water were comprised of washout from the cement and fly ash rather than basin sludge sediment.

\subsubsection{Grout/CLSM Placement and Dewatering System Design}

The engineering design of the basin dewatering and grout/CLSM placement system was initiated in October 2005. The dewatering and grout/CLSM placement system is described in detail in Section 2.4 of DOE/NE-ID-11214, "Removal Action Work Plan for the CPP-603A Basin Facility." The final design package for the project was approved in June 2006.

\subsubsection{Set-up and Test Grout/CLSM Placement and Dewatering Systems Offsite}

To confirm the implementability of the dewatering and grout/CLSM placement system designs, a mock-up of the system was constructed. Three demonstration basins were constructed and filled with water to a minimum depth of 4 feet. Approximately $1 / 2$ inch to 1 inch of nonradioactive surrogate sediment was spread over at least half of the floor of the demonstration basins.

Batches of the selected test mixtures of grout/CLSM were pumped into the basins through tremie pipes located within 3 inches of the settled sediments and were allowed to flow up to 81 feet along the bottom of the basins. Various mixtures of grout/CLSM were tested to identify the mix with best flowability and self-leveling capabilities.

In addition to the surrogate sediment, a pile of ten 8-inch pumice blocks was placed in each test basin. The blocks were placed in the basins to test the flowability of the grout mixtures and the ability of the mixes to fill void spaces in the "hot waste boxes" located in the South Basin. 
As a result of the mock-up testing, the final design and grout/CLSM mixtures were refined and the implementability of the systems was confirmed. Based on knowledge gained from the mock-up, applicable changes to the full scale systems were made prior to installation at INTEC.

\subsubsection{Complete Required Building Modifications}

The facility modifications described in Section 2.4.3 of DOE/NE-ID-11214, "Removal Action Work Plan for the CPP-603A Basin Facility," were started in April and completed in July 2006. These modifications included penetrations through the exterior walls of the facility and modifications to deck plates over the North and Middle Basins.

\subsubsection{Prepare and Approve Grout/CLSM Placement and Dewatering Project Work Orders}

The preparation of the internal work documents implementing basin dewatering and grout/CLSM placement was started in February and completed in August 2006. These work documents include Project Work Orders and task specific work procedures.

\subsubsection{Complete the Management Self-Assessment}

Prior to initiating dewatering and grout/CLSM placement, CH2M-WG Idaho, LLC (CWI) conducted a management self-assessment (MSA). The function of the MSA was to assess the project's preparedness for safe operation. It included a review of project documentation, systems, training, work control process, and emergency response. The CPP-603A dewatering and grout/CLSM placement MSA started in July and culminated with the project receiving authorization to start up August 21, 2006.

\subsubsection{Construction of the Grout/CLSM Batch Plant}

To support the CPP-603A basin dewatering and grout/CLSM placement as well as other projects at INTEC, including Tank Farm Closure, a subcontract was executed to establish a cement batch plant east of INTEC outside of the security fence. The batch plant was capable of producing custom grout mixes at a rate to support grout/CLSM placement at CPP-603A. Grout/CLSM was delivered from the batch plant to CPP-603A in cement trucks with a capacity of $10 \mathrm{yd}^{3}$.

\subsubsection{Summary of Events}

Upon completing the necessary preparation steps and receiving management authorization, dewatering and grout/CLSM placement was initiated August 22, 2006.

\subsubsection{Pumped Water to ICDF}

On August 22, 2006, the first basin water was pumped to ICDF. The first grout/CLSM was placed in the North Basin on August 23, 2006. Basin water pumping continued on a 5-day/week, 10-hour/day schedule during routine operation. The last of the basin water was pumped to the ICDF evaporation ponds on November 3, 2006. Basin water was pumped from below the water surface in the overflow pit through carbon steel pipe with duplex filters and totalizing flow meter in line. Outside of CPP-603, the transfer piping transitioned to 3-inch high density polyethylene (HDPE) through the remaining route to the ICDF evaporation ponds as described in Section 2.4.4, Water Removal System Design in the Removal Action Work Plan. 


\subsection{Volume of Water Pumped}

A total volume of 1,191,842 gal of basin water was pumped from CPP-603A to the ICDF evaporation ponds. The discrepancy between the volume of water actually pumped and the 1,519,000 gal estimated in the Removal Action Work Plan is due to: (1) the estimates in the Removal Action Work Plan did not exclude the volume already filled by beams, columns, and debris within the basin system, and (2) some unmeasured volume of basin water was incorporated into the grout/CLSM mixture as it was placed into the basin system and solidified.

\subsubsection{Placed Grout/CLSM in the Basins}

Grout/CLSM was pumped into the CPP-603 basin system as described in Section 2.4 of the Removal Action Work Plan. Two grout/CLSM mixture recipes were utilized in the basin system. Mix 1 was specifically designed to be very flowable and self-leveling. Mix 1 was used for the initial pours to encapsulate any residual sludge that may have remained in the basins and debris on the bottom of the basins. However, some of the pipes and hoses left in the basins, as well as debris piles, were configured in such a way that could trap water in the pipe or hose sections. As a result, it is possible that small volumes of water were not completely displaced by the grout/CLSM and could be encountered during future remediation. The water is fully encapsulated now, but future workers should be aware that it may exist. Mix 2 contained a large fraction of sand and smaller amounts of fly ash and cement. Due to the composition of materials in Mix 2, it was less flowable. Because it contained less fly ash, Mix 2 tended not to increase the water $\mathrm{pH}$ as drastically as Mix 1. Mix 2 was used to fill the majority of the void space in the basin system.

\subsection{Volume of Grout/CLSM Pumped}

A total volume of $6,527 \mathrm{yd}^{3}$ of grout/CLSM was pumped into the CPP-603A basins. The discrepancy between the volume of grout/CLSM actually pumped into the basins and the 7,516 $\mathrm{yd}^{3}$ of grout/CLSM estimated in the Removal Action Work Plan is because the estimates in the Removal Action Work Plan did not exclude the volume in the basins already filled by beams, columns, and debris within the basin system.

\subsubsection{Demobilization}

Demobilization activities were started immediately upon completing a visual inspection that confirmed all the voids in the basin system had been filled to the prescribed level of 4 in. \pm 2 in. from the top edges of the basin walls, and no basin water was present on top of the grout/CLSM. Demobilization included cleaning and removing the grout pumps and flushing, and disassembling and disposing the grout hoses and tremie pipes. The transfer pipe from CPP-603 to the ICDF evaporation ponds was rinsed with three volumes of clean water and the low spots in the line were tapped and drained to prevent damage from freezing until the pipeline is dismantled. All waste associated with dewatering and grout/CLSM placement was collected and disposed of depending on its characterization.

Penetrations through the walls of CPP-603 will be repaired, and tripping hazards throughout the basin area were mitigated. The 3-inch carbon steel discharge piping inside of CPP-603 will be rinsed, disassembled, and disposed of to restore access to the waste treatment area in the east end of the East - West truck bay.

\subsubsection{Final Facility Status}

With completion of Non-time Critical Removal Action at the CPP-603A Basins, long-term surveillance and monitoring of the effectiveness of the action will be evaluated as part of the CERCLA 
Five-year Review process. Information gathered from long-term radiological surveys and surveillance conducted by facility operation personnel will be evaluated to determine if the remedy remains effective and the removal action goals are achieved.

Radiation levels have been reduced in all areas with the North Basin showing the greatest reduction and the Transfer Channel showing the least. This provides an indication that the scum line around the basins has been covered. Contamination levels on deck surfaces and walkways remain at or near the pregrout levels. Contamination levels on the grout surfaces appear to be less than the deck surfaces. Airborne activity remains at the same level as pre-grouting. Additional surveys and increasing survey frequencies have been established to provide long term monitoring of the basin radiological conditions.

A summary of Pre-grouting and Post-grouting Radiological conditions is presented in Table 1.

Table 1. Pre-grouting and post-grouting radiological conditions in CPP-603A.

\begin{tabular}{|c|c|c|c|c|c|c|c|c|}
\hline \multirow{2}{*}{$\begin{array}{l}\text { Basin } \\
\text { Area }\end{array}$} & \multicolumn{2}{|c|}{ Radiological Posting } & \multicolumn{2}{|c|}{ Radiation Levels } & \multicolumn{2}{|c|}{ Contamination Levels } & \multicolumn{2}{|c|}{ Air Activity } \\
\hline & Pre-Grout & Post-Grout & Pre-Grout & Post-Grout & Pre-Grout & Post-Grout & Pre-Grout & Post-Grout \\
\hline $\begin{array}{l}\text { North } \\
\text { Basin }\end{array}$ & $\begin{array}{l}\text { Radiation/ } \\
\text { Contamination }\end{array}$ & $\begin{array}{l}\text { Radiation/ } \\
\text { Contamination }\end{array}$ & $\begin{array}{l}4-10 \\
\mathrm{mR} / \mathrm{hr}\end{array}$ & $\begin{array}{l}1 \mathrm{mR} / \mathrm{hr} \text { or } \\
\text { less }\end{array}$ & $\begin{array}{l}\text { Low } \\
\text { Level* }\end{array}$ & Low Level & $\begin{array}{l}<0.02 \\
\text { DAC** }\end{array}$ & $<0.02 \mathrm{DAC}$ \\
\hline $\begin{array}{l}\text { Middle } \\
\text { Basin }\end{array}$ & $\begin{array}{l}\text { Radiation/ } \\
\text { Contamination }\end{array}$ & $\begin{array}{l}\text { Radiation/ } \\
\text { Contamination }\end{array}$ & $\begin{array}{l}8-10 \\
\mathrm{mR} / \mathrm{hr}\end{array}$ & $\begin{array}{l}1-2.5 \\
\mathrm{mR} / \mathrm{hr}\end{array}$ & Low Level & Low Level & $\begin{array}{l}<0.02 \\
\text { DAC }\end{array}$ & $<0.02 \mathrm{DAC}$ \\
\hline $\begin{array}{l}\text { South } \\
\text { Basin }\end{array}$ & $\begin{array}{l}\text { Radiation/ } \\
\text { Contamination }\end{array}$ & $\begin{array}{l}\text { Radiation/ } \\
\text { Contamination }\end{array}$ & $\begin{array}{l}3-4 \\
\mathrm{mR} / \mathrm{hr}\end{array}$ & $2 \mathrm{mR} / \mathrm{hr}$ & Low Level & Low Level & $\begin{array}{l}<0.02 \\
\text { DAC }\end{array}$ & $<0.02 \mathrm{DAC}$ \\
\hline $\begin{array}{l}\text { Transfer } \\
\text { Channel }\end{array}$ & $\begin{array}{l}\text { Radiation/ } \\
\text { Contamination }\end{array}$ & $\begin{array}{l}\text { Radiation/ } \\
\text { Contamination }\end{array}$ & $\begin{array}{l}3-8 \\
\mathrm{mR} / \mathrm{hr}\end{array}$ & $\begin{array}{l}1-8 \\
\mathrm{mR} / \mathrm{hr}\end{array}$ & Low Level & Low Level & $\begin{array}{l}<0.02 \\
\mathrm{DAC}\end{array}$ & $<0.02 \mathrm{DAC}$ \\
\hline $\begin{array}{ll}* & \text { Low leve } \\
& \text { demonst } \\
* * & \text { DAC }=\mathrm{I}\end{array}$ & $\begin{array}{l}\text { less than } 5,000 \text { dis } \\
\text { s that there has bee } \\
\text { ved Air Concentrat }\end{array}$ & ations per minute & $1^{2}$ beta-gamn & $\begin{array}{l}\text { a smear or les } \\
\text { activities. }\end{array}$ & an 50,000 disi & tions per minu & a large area & This \\
\hline
\end{tabular}

A CPP-603 Basin Dewatering/Grouting Project Closeout Plan was prepared by CWI and contained a list of items that must be closed before the Project could be considered complete. The list of items includes issues such as draining and disposition the water and grout pumps, confirming the area has been cleaned up and waste/trash has been disposed, the Temporary Accumulation Areas have been closed out, and so on. A closeout criteria was identified for each item on the list. When each item is closed and the applicable evidence of closure provided, a final closeout report will be prepared by the project engineer officially closing the Project.

\subsubsection{Cost}

The activities conducted within the scope of this Removal Action included consolidation of the nonuranium containing debris, which occurred as part of the sludge removal activities and has not been isolated as a unit cost element. Management of SHADO 1 is estimated to cost approximately $\$ 1 \mathrm{M}$, surveillance and maintenance for an additional 20 years is assumed to add $\$ 1 \mathrm{M}$, and removal, treatment, and disposal of basin water and placement of grout/CLSM is estimated at approximately $\$ 6 \mathrm{M}$. Based on these estimates, the total Removal Action costs were approximately $\$ 8 \mathrm{M}$, as shown in Table 2 . For completeness, the costs of the other significant activities that prepared the CPP-603A basin system for dewatering and grout/CLSM placement included removal, treatment, and disposal of basin sludge added $\$ 11.3 \mathrm{M}$ to the total project cost of approximately $\$ 19.3 \mathrm{M}$. 
Table 2. Project costs.

\begin{tabular}{|c|c|c|c|}
\hline \multirow[b]{2}{*}{ Activity } & \multicolumn{2}{|c|}{ Estimates from Action Memorandum } & \multirow{2}{*}{$\begin{array}{c}\text { Total Activity Costs } \\
\text { (Actual Incurred } \\
\text { Project Cost) }\end{array}$} \\
\hline & Estimated Cost & Net Present Value & \\
\hline SHADO 1 Management & $\mathrm{N} / \mathrm{A}^{*}$ & $\mathrm{~N} / \mathrm{A}^{*}$ & $\$ 1,000,000$ \\
\hline Basin Water Disposal to ICDF & $\$ 509,000$ & $\$ 495,000$ & $\$ 1,700,000$ \\
\hline Grout/CLSM Placement & $\$ 613,000$ & $\$ 595,000$ & $\$ 3,700,000$ \\
\hline Project Management and Support & $\$ 504,000$ & $\$ 490,000$ & $\$ 600,000$ \\
\hline Surveillance and Maintenance & $\$ 1,000,000$ & $\$ 656,000$ & $\$ 1,000,000$ \\
\hline Total & $\$ 2,626,000$ & $\$ 2,236,000$ & $\$ 8,000,000$ \\
\hline
\end{tabular}

The discrepancies between the estimates provided in the Action Memorandum and the actual incurred project costs are attributed to a major increase in cement costs for grout/CLSM that occurred during the period while sludge removal, treatment, and disposal was taking place. Additional increases were incurred as a result of unforeseen costs associated with the issues described below in Section 5, Lessons Learned. Surveillance and maintenance costs were not estimated for Total Activity Costs but are assumed to be similar to those estimated for the Action Memorandum.

In addition to the monetary costs associated with the activities that took place in the basin system, worker exposure to radiation was incurred. Approximately 14 man-rem was taken to accomplish sludge removal. Approximately 2 man-rem of exposure was taken during dewatering and grout/CLSM placement in the basin system.

\subsubsection{Characterization Data}

Pre-dewatering Basin Water Characterization - Sampling procedure SPR-126, "Characterization of CPP-603 Basin Water and In-line Filters (ESP-016-06)," was prepared and implemented to characterize the basin water in CPP-603. The basin water was sampled and analyzed to confirm that the character of the water had not been significantly degraded by sludge removal activities. Sampling and analysis confirmed that the quality of the basin water had improved as a result of sludge removal.

EDF-4666 demonstrated that the basin water met all ICDF WAC and determined the concentration of radionuclides in the sediment limits the amount of sediment that could remain suspended in the water as total suspended solids (TSS) to about $500 \mathrm{mg} / \mathrm{L}$, to maintain the total radionuclide concentration in the water below the ICDF concentration limits. This limit was defined by the amount of barium- $137 \mathrm{~m}$ (Ba-137m) in the sediment. Near the end of the grout/CLSM placement process, the $500 \mathrm{mg} / \mathrm{L}$ TSS limit was eliminated as a procedural requirement after it was confirmed analytically that the solids suspended in the basin water were comprised of washout from the cement and fly ash rather than basin sludge sediment.

In-line Total Suspended Solids and pH Monitoring - As described in Section 2.4.4.1 of the Removal Action Work Plan, routine monitoring of TSS and $\mathrm{pH}$ was conducted at a sample point downstream of the duplex filters. Sampling and analysis for TSS and $\mathrm{pH}$ are described in sampling procedure SPR-126. Data collected was recorded in the project logbooks and was used to determine if transfer of the basin water to ICDF could continue. 
Water Filter Characterization - Sampling procedure SPR-126 described analysis of the filter from the duplex filter to support hazardous waste determinations for filter management and disposal. However, because of the potential radiological exposure to workers collecting samples from the filters, and problems associated with obtaining adequate volume of material for analysis, it was decided that declaring the spent filters as mixed waste would be safer and more cost effective.

Nuclear Material Accountability Sampling - Sampling procedure SPR-126 also described collecting samples at least daily from the in-line sampling port downstream of the duplex filters and having them analyzed for uranium. The data were collected and provided to the Safeguards and Security organization for special nuclear materials accountability purposes.

\section{ACHIEVING THE REMOVAL ACTION OBJECTIVES}

Implementation of this removal action is consistent with the remedial action objectives established in the Final Record of Decision (DOE-ID 1999). As such, the removal action will be consistent with and will contribute to the overall remediation of INTEC under CERCLA (42 USC $\S 9601$ et seq.). The removal action objectives identified in Section 4.1.1 of the Action Memorandum (DOE-ID 2005) for this non-time-critical removal action were achieved as follows:

- Reduction of the risk to the Snake River Plain Aquifer was achieved by removing the water from the CPP-603A basins and disposing of it at the ICDF evaporation ponds. The basin water is no longer a driving force capable of moving existing vadose zone contaminants to the aquifer.

- Disposal of the basin water to the ICDF evaporation ponds provided the mechanism for the permanent, safe disposition of radioactive water previously in the CPP-603A basins. Placement of the grout/CLSM has shielded the cobalt-60 contaminated objects as well as other nonuranium containing debris and rubbish by encapsulating the material on the bottom of basins until an end state for the CPP-603 Complex is identified.

- $\quad$ The risk posed by contaminants associated with the CPP-603A basins was evaluated in the engineering evaluation/cost analysis (EE/CA). The streamlined risk assessment demonstrated that the risk associated with the CPP-603A basin system did not exceed a cumulative carcinogenic risk level of $1 \times 10-4$ and a total hazard index of one for future residents in 2095 and for current workers. EDF-4488, "Streamlined Risk Assessment for the CPP-603 EE/CA," states "Based on this streamlined risk assessment, filling the basins and canals with soil or grout, while leaving all current source inventory in place, results in predicted groundwater concentrations that meet the required performance criteria. For groundwater, the performance criterion is to prevent migration of contaminants from the CPP-603A Basins that would cause the Snake River Plain Aquifer (located outside the INTEC security fence) to exceed a cumulative carcinogenic risk level of $1 \times$ 10-4, a total hazard index of one, or applicable State of Idaho groundwater quality standards in 2095 and beyond. Note that the contribution to risk is sufficiently below the 10-4 risk standard (at least a factor of 55 if filled with soil and 450 if filled with grout) so that based on this analysis, CPP-603 is not a significant contributor to cumulative risk."

- $\quad$ EDF-4488 was prepared based on an assumption that all of the basin sludge was left in place prior to grouting. The risk described in EDF-4488 has been further reduced following implementation of this action which followed removal of all basin sludge to the degree practical. 
- Migration of contaminants and minimization of the risk posed by contaminants remaining at the CPP-603A basins was prevented after the removal action so it does not exceed a cumulative carcinogenic risk level of $1 \times 10-4$ and a total hazard index of one for future residents in 2095. This is demonstrated by the risk described in EDF-4488, as described above and the additional mitigation achieved by removal of the basin sludge prior to grouting. Current workers are protected as a result of removal and disposal of the basin water and the $6,527 \mathrm{yd}^{3}$ of grout/CLSM placed in the basin to shield and encapsulate any residual radioactivity.

The removal action goals were predicated on the current and future land uses established for INTEC in the Final Record of Decision (DOE-ID 1999), which includes industrial land use until at least 2095. The groundwater-ingestion exposure pathway was assumed to be the only viable exposure pathway. A surface exposure pathway does not exist from CPP-603A, since the nonuranium containing debris is present at least 20 feet below ground surface, the water has been removed, and the basins have been filled with an inert grout/CLSM material. This is consistent with the Final Record of Decision (DOE-ID 1999), where surface pathway risks are assumed to occur for contamination from ground surface to 10 feet below ground surface.

\section{PHOTOS}

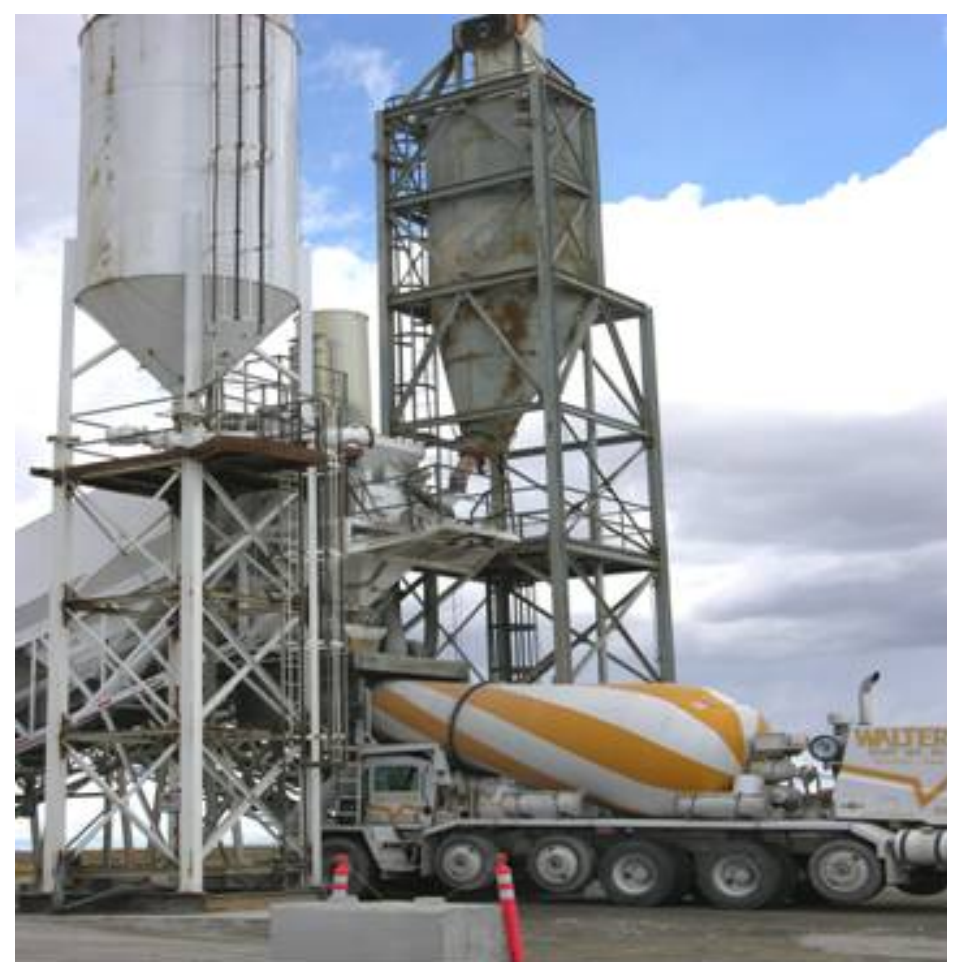

Figure 1. Grout Batch Plant. 


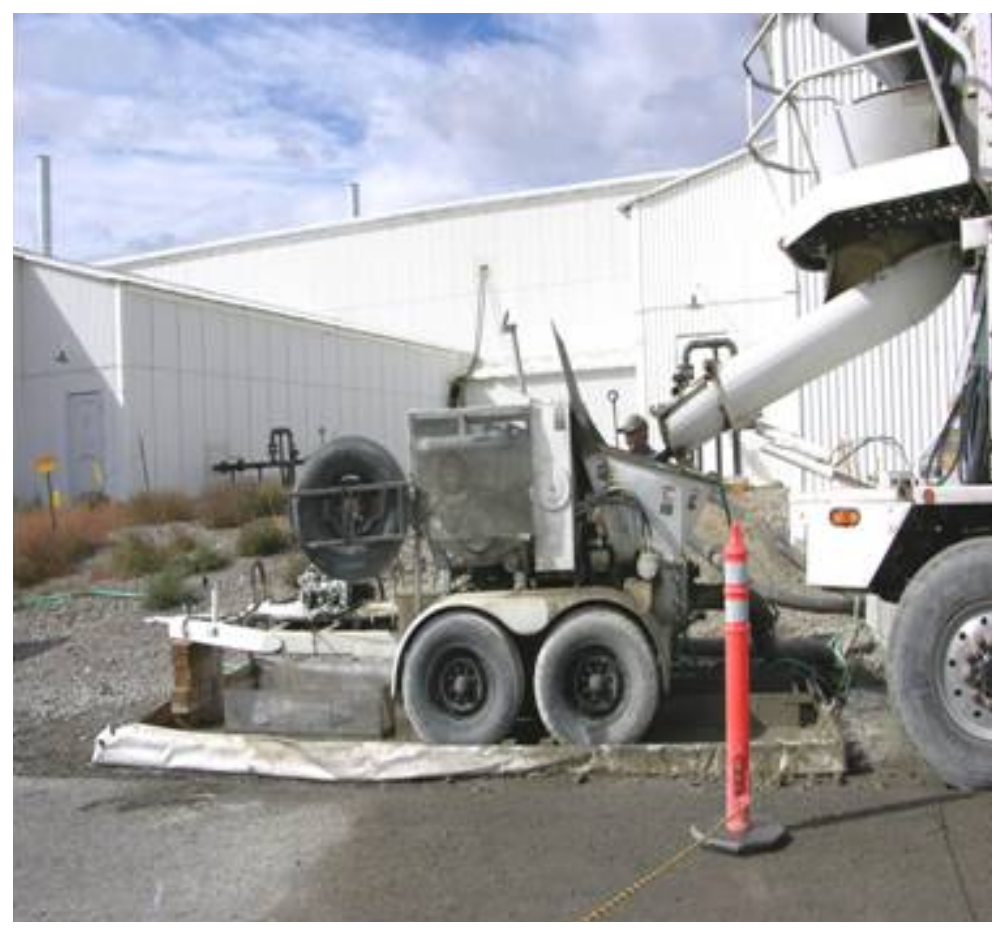

Figure 2. Grout/CLSM Pump.

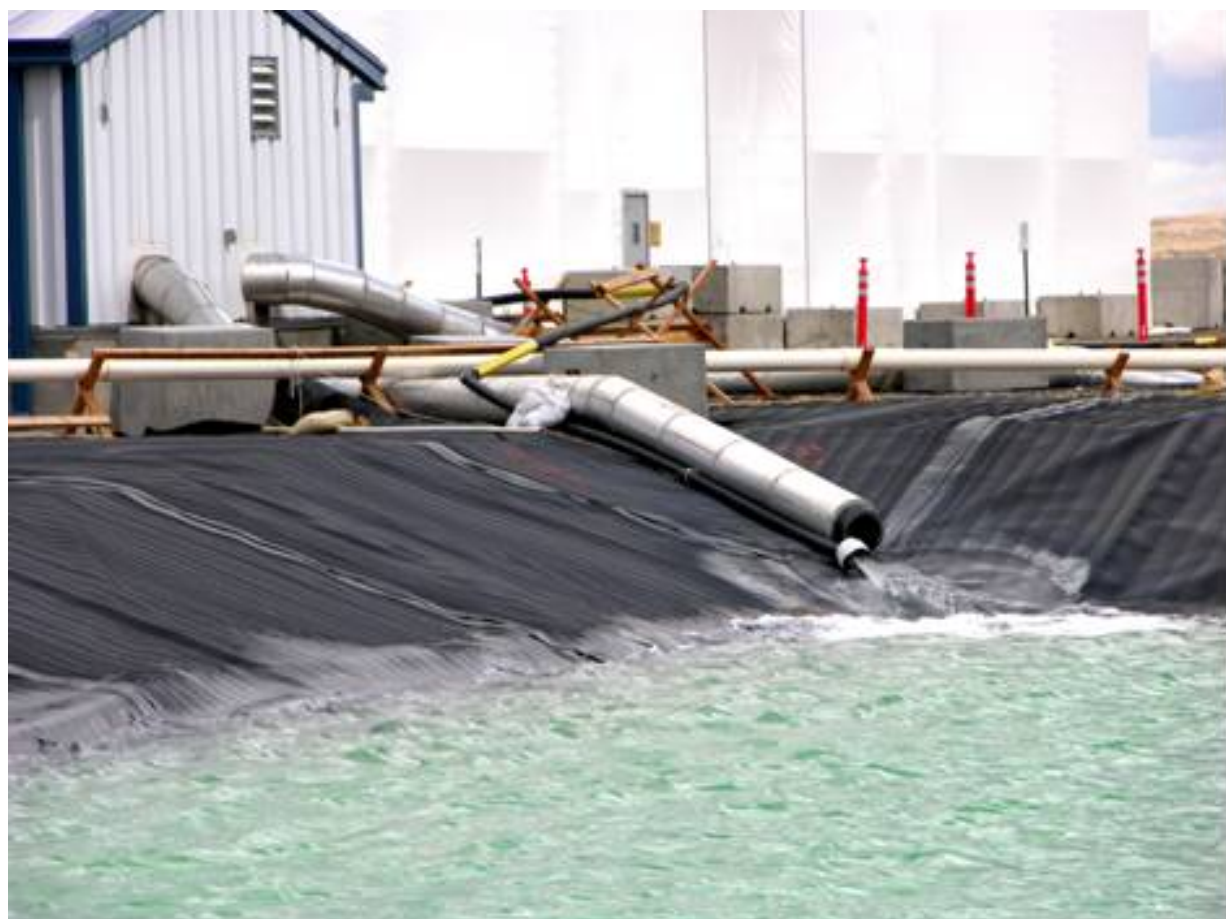

Figure 3. Basin Water Discharge to ICDF Evaporation Pond. 


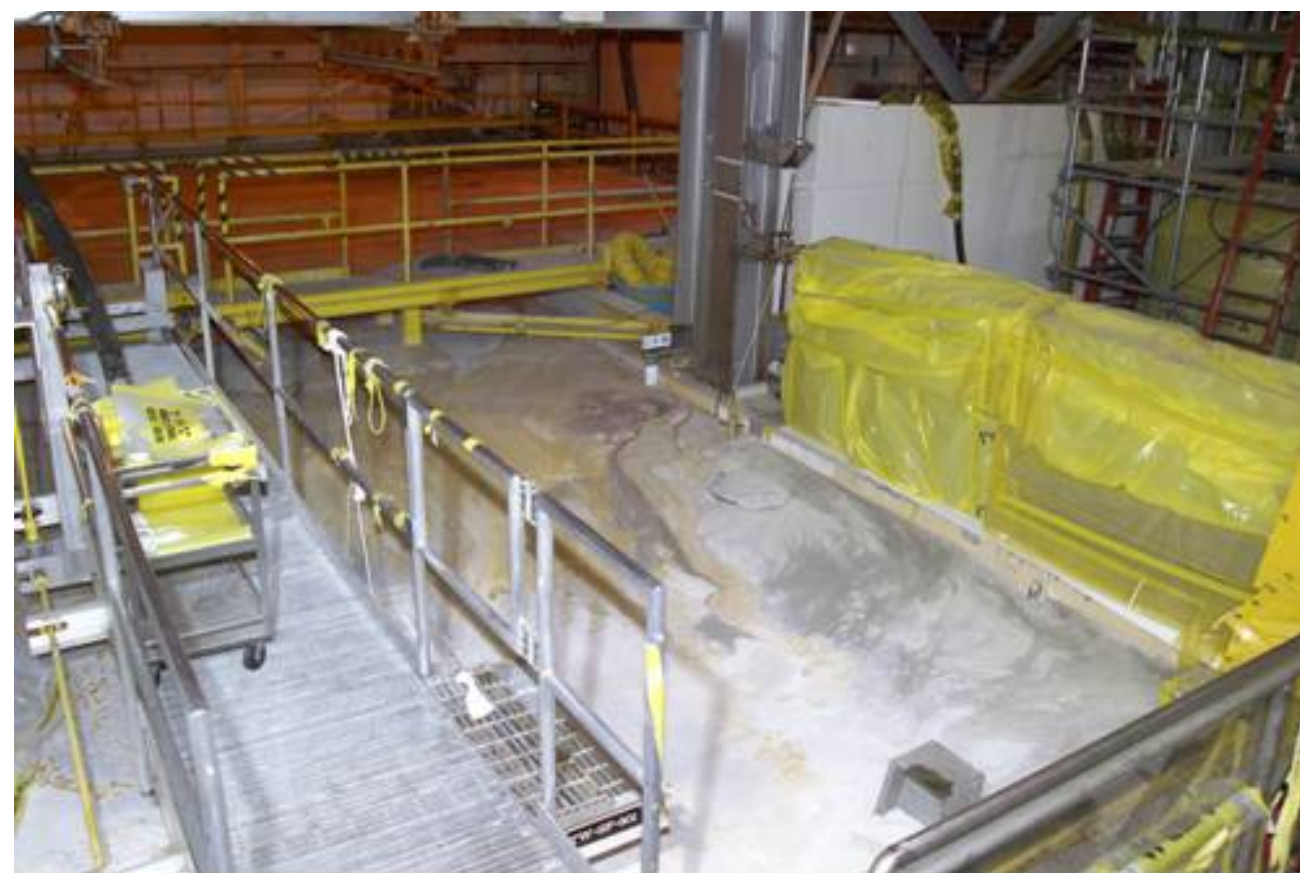

Figure 4. Grouted South Unloading Pit.

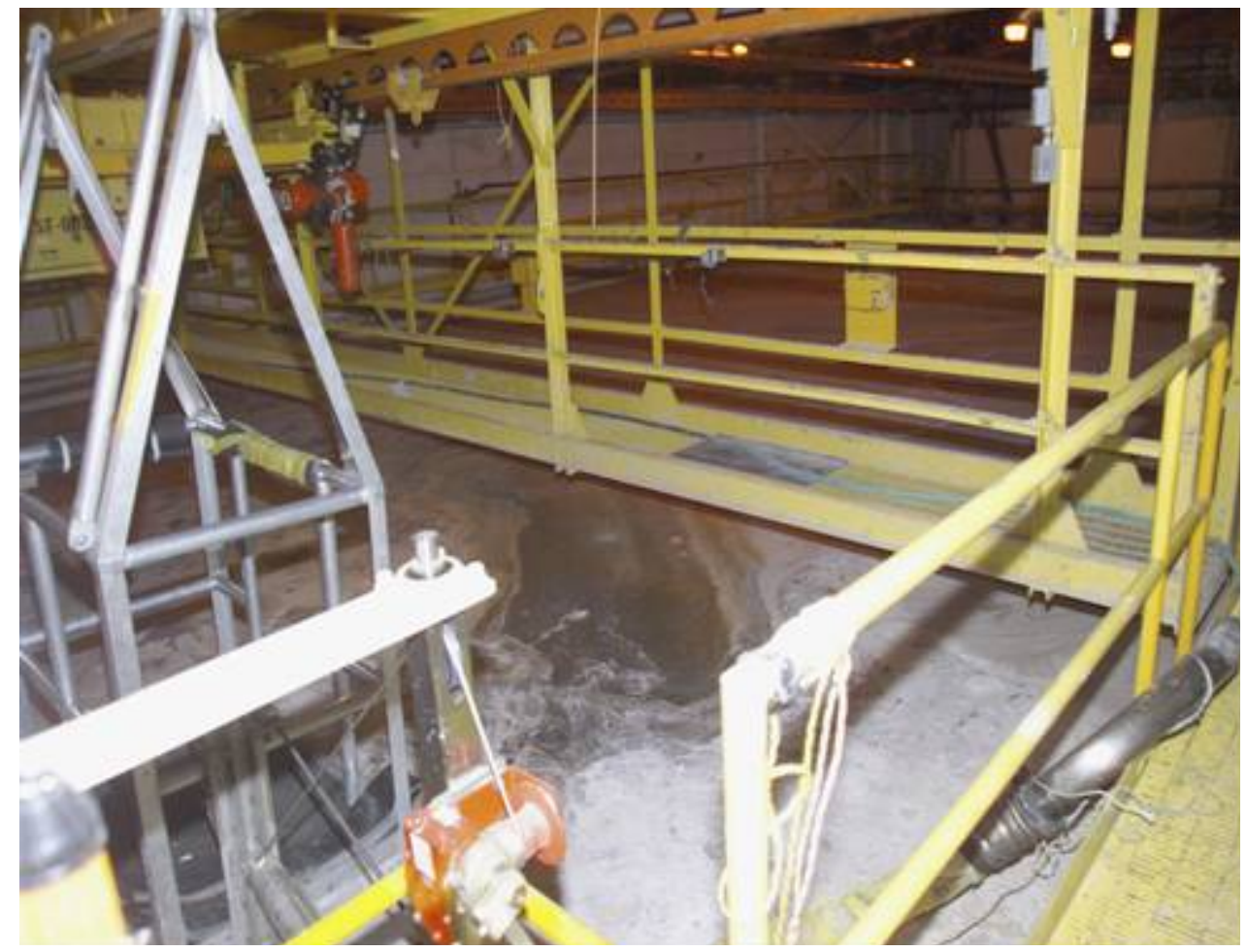

Figure 5. Grouted South Basin. 


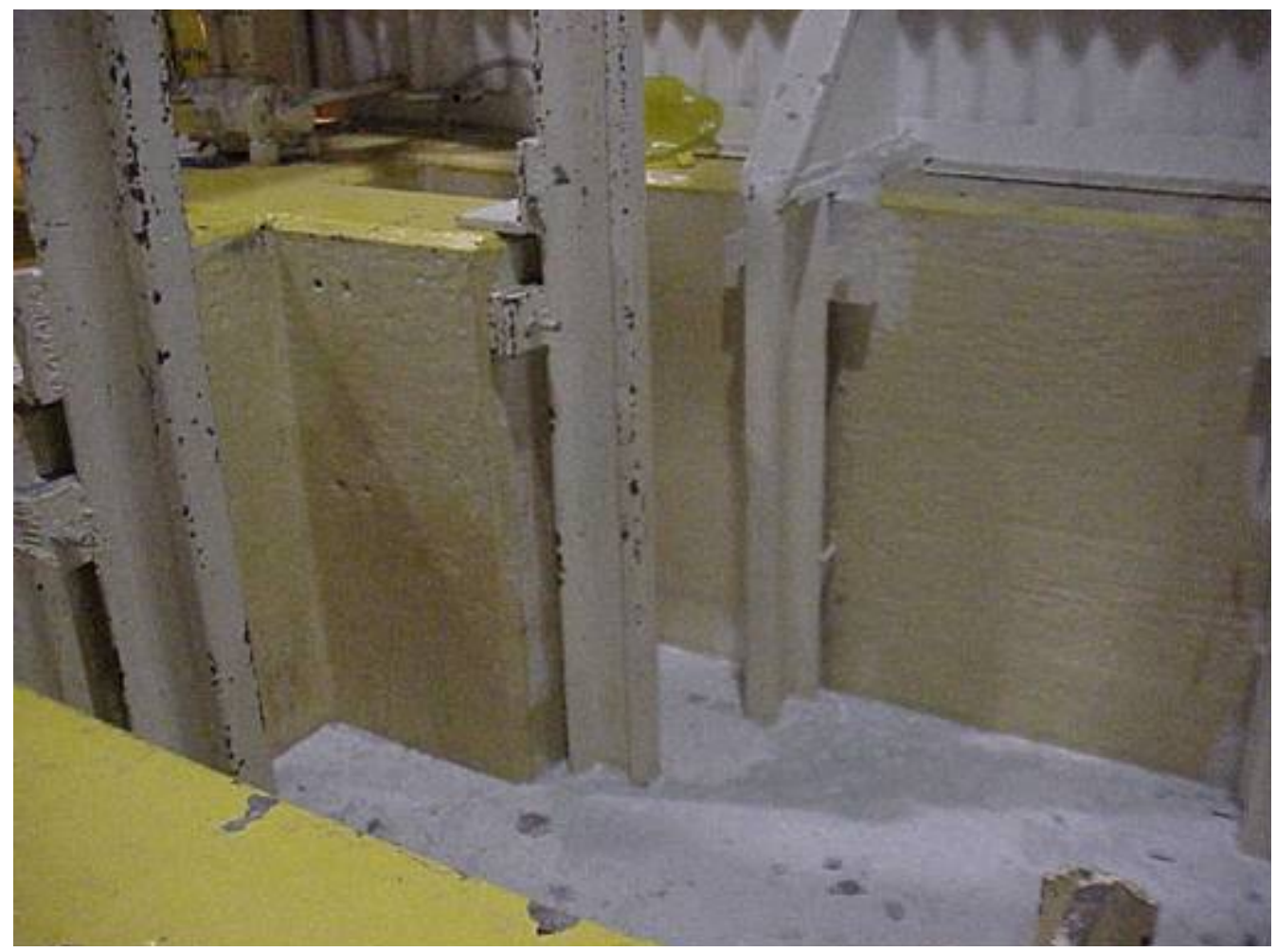

Figure 6. Grouted North Unloading Pit.

\section{LESSONS LEARNED}

Throughout the implementation of the Removal Action, challenges and problems were encountered that were not foreseen during the planning and scheduling phases. Provided below are some of the more significant issues encountered during the implementation of the Removal Action and the corrective actions taken to overcome the problems.

\section{Fly Ash Material Change}

The biggest delays in the project were the result of changing the class of fly ash used in the grout. Fly ash comes in two major classes, designated Class C and Class F. Mock-up tests were done using Class F, and the specification for the batch plant was for Class F. However, when the batch plant went into operation, the availability of Class $\mathrm{F}$ was severely limited, and Class $\mathrm{C}$ was substituted. The grout recipe was adjusted for Class $\mathrm{C}$ fly ash, but the new mix was not tested prior to pumping it into the basin. On day one of grouting operations, the grout mix was too thick, and only a few truck loads were pumped. After some additional adjustments and testing with full truck loads the next day, a new recipe was identified which was much more workable. The new mix had satisfactory flow and strength characteristics, but expected $\mathrm{pH}$ levels were affected by the different fly ash material.

The mock-up tests had indicated the highest $\mathrm{pH}$ to be expected with Class $\mathrm{F}$ fly ash was about 12.3. Calculations accounting for the different compositions of the two fly ashes showed that even the Class $\mathrm{C}$ fly ash would not reach a $\mathrm{pH}$ of 12.5 . The grouting experience, however, proved that the Class $\mathrm{C}$ fly ash could produce a $\mathrm{pH}$ higher than the 12.5 . As a $\mathrm{pH}$ of 12.5 was approached, the project shut down for 2 weeks, pending development and implementation of corrective actions. 
Several options were evaluated. The preferred approach was to add nitric acid directly into the basins to lower the $\mathrm{pH}$. It was determined that 760-1500 liters (200-400 gallons) of 13 molar acid would be required. Safety considerations in manually handling that amount of acid impacted the use of this option. Since the water from the CPP-603 basin was addressed under a CERCLA removal action and INTEC is within the area of contamination, discussions were held with the Idaho Department of Environmental Quality (DEQ) and U.S. Environmental Protection Agency (EPA) to discuss potential options. The technical limit for the ICDF evaporation ponds is based on the design limitations of the liners, which can handle a $\mathrm{pH}$ of 13 , so it was determined that it was permissible to increase the $\mathrm{pH}$ of the basin water to 12.85 . However, the maximum $\mathrm{pH}$ seen was 12.77 . Only about 151,000 liters $(40,000$ gallons) of water were transferred to the ICDF evaporation ponds at a $\mathrm{pH}$ of 12.5 or higher.

\section{Grout/CLSM Line Plugging}

Some delays also occurred as a result of grout lines becoming plugged. This was not prevalent on days when high volumes of grout were pumped, but on days when low volumes were pumped, the grout had time to begin to set up in the lines. Twice during cleanout operations, which involved pushing a foam ball through the line with water pressure, the rupture disc burst. The line was cleaned out manually and the rupture disc replaced. No rupture discs burst during grouting operations.

Because of a desire to keep the lines from plugging during the all-day grouting operations, the project pumped a couple hundred liters (a few dozen gallons) of water through the lines every 2 hours. This proved to be counter-productive with the back-fill grout mix that contained sand. The cementations materials were carried away and the sand left behind. This caused high back pressure when grouting was resumed, and on some occasions the operation had to be stopped and the lines cleaned out manually.

Tremies became stuck several times, when the grout around the tremie was deeper than the overall grout level. In most cases the tremies were able to be freed later, but in two cases they were abandoned and remain grouted in the basin. Alternate grout placement locations were readily made. Additionally, the tremies were raised more frequently to minimize the amount of grout mounding around them.

\section{Total Suspended Solids (TSS) Increase}

Near the end of the basin water pumping process, significant increases in the TSS in the basin water were noted during routine daily monitoring. The increase in solids was attributed to wash out of cement and fly ash particles from the grout/CLSM and the decreasing volume of water remaining in the basins. Early calculations in EDF-4666 based on specific reference radioisotopes had indicated that maintaining TSS concentrations below $500 \mathrm{mg} / \mathrm{L}$ would ensure compliance with the ICDF WAC, assuming the TSS was comprised primarily of residual basin sludge. As a result, a TSS limit was placed on the water pumped to ICDF. As the TSS approached the limit, additional analysis was conducted as described in EDF-7478, "CPP-603 Basin Water Removal of TSS Monitoring," to confirm that the TSS was not comprised of basin sludge but rather due to the increase in cement and fly ash washout. The reference isotopes (barium-137m/cesium-137) were confirmed to have not increased but remained below the WAC limits. Analysis confirmed the reference isotopes were at least two orders of magnitude below the WAC limits for barium-137m. This condition was discussed with the EPA and the DEQ and, because there was not a specific WAC limitation for TSS, an agreement was reached that the water did not exceed WAC limitations and continued pumping water in excess of $500 \mathrm{mg} / \mathrm{L}$ TSS was acceptable for disposal at the evaporation ponds. 


\section{Hydrogen Generation}

During grouting of the CPP-603A basin sludge, a report (EM-RL-PHMC-SNF-2005-002) was issued from the DOE Occurrence Reporting and Processing System discussing the generation of hydrogen during grouting of basin sludge at the Hanford, Washington, nuclear reservation. The sludge removal and solidification process at the CPP-603A basin facility was determined to involve similar chemistry, and therefore, similar issues with hydrogen generation. The primary source of hydrogen generation was a series of chemical reactions between the caustic grout and aluminum metal. Grouting was suspended pending further engineering evaluation.

Reaction rates and, therefore the rate of hydrogen generation, depend on the amount of aluminum metal present in the sludge or basin, and on the surface area of the aluminum metal pieces. Experimental data indicate that within 3 hours of grout addition, hydrogen generation essentially stops, because the aluminum metal develops a protective oxide layer. A study of the CPP-603A basin sludge solidification process concluded that hydrogen could be generated during basin grouting and in the high integrity containers that were used to solidify sludge (EDF-6677). Under conservative assumptions for aluminum mass, configuration, and leak paths for dissipation of hydrogen from each fill-head, the rapid rate of hydrogen generation during mixing could lead to a hydrogen concentration of $4 \%$ (the lower flammability limit for hydrogen) within about 16 minutes.

Compensatory measures described in SER-JCO-1 were put in place for high integrity container (HIC) grouting. An active ventilation system was implemented to sweep any hydrogen generated out of each fill-head's air space. The system consisted of a chimney attached to the sample port opening on each fill-head and two air-movers. The air movers were connected in parallel and drew a minimum of $56 \mathrm{~L} / \mathrm{m}$ $(2 \mathrm{cf} / \mathrm{m})$ of ambient air through each fill-head for a minimum of 3 hours after grout addition. HIC grouting operations were resumed and continued without incident.

Prior to movement of each HIC, its fill-head was removed and replaced with a vented lid. The grouted HICs sat for several hours while the grout hardened sufficiently to allow transport of the HIC. These factors provided assurance that a flammable atmosphere could not exist in any of the already grouted HICs.

A similar evaluation was conducted for basin grouting. Based on the inventories of aluminum remaining in the basins, dispersion mechanisms, and flow paths, it was determined that hydrogen concentrations would not reach $4 \%$ during basin grouting. Therefore, no mitigative actions were necessary. During basin grouting, bubbling was evident in a localized area of the South Basin directly above a box of debris. Monitoring of the gas indicated it to be hydrogen, but at a concentration significantly less than the $4 \%$ lower flammability limit. However, bubbling was observed over a period of several weeks, contrary to the 3 hours indicated by experimental data.

\section{$\underline{\text { Freeze Protection }}$}

As the action moved into the late autumn, freezing of the discharge line from CPP-603 to the ICDF evaporation ponds became an issue. To prevent freezing of the line, low flow transfers of water from the basins were scheduled for late evenings and night to provide water movement in the piping during the coldest part of the day. Maintaining low flows of water through the transfer pipe through the night proved effective in keeping the discharge line from freezing. 


\section{REFERENCES}

Action Memorandum for the Non-Time Critical Removal Action at the CPP-603A Basins, Idaho Nuclear Technology and Engineering Center, as evaluated in the Engineering Evaluation/Cost Analysis for the CPP-603A Basin Non-Time Critical Removal Action, Idaho Nuclear Technology and Engineering Center.

DOE/ID-11260, “Characterization Plan for Soils Around Drain Line PLA-100115.”

DOE/NE-ID-11214, "Removal Action Work Plan for the CPP-603A Basin Facility."

EDF-4488, "Streamlined Risk Assessment for the CPP-603 EE/CA."

EDF-4666, "Comparison of CPP-603 Basin Effluent to ICDF WAC."

EDF-6677, "Hydrogen Gas Generation in CPP-603 Sludge, High Integrity Containers, and Grout.”

EDF-7478, “CPP-603 Basin Water Removal of TSS Monitoring."

Engineering Evaluation/Cost Analysis for the CPP-603A Basin Non-Time Critical Removal Action, Idaho Nuclear Technology and Engineering Center.

HWMA/RCRA Less Than 90-day Generator Closure Report for the VES-SFE-126 (INEEL 2000).

SER-JCO-1, “ U.S. Department of Energy, Idaho Operations Office, Approval of the Justification for Continued Operations for Grouting of Basin Sludge in High Integrity Containers in the CPP-603 Basin Facility."

SPR-126, "Characterization of CPP-603 Basin Water and In-line Filters (ESP-016-06)."

Water Removal System Design in the Removal Action Work Plan. 